\title{
Effects of Riboflavin on Gunn Rats under Phototherapy
}

\author{
L. BALlOWITZ, A. BUNJAMIN, F. HANEFELD, L. LIETZ, G. STÜTTGEN, AND D. WIRJADI \\ Children's Hospital of the Free University Berlin, Kaiserin Auguste Victoria Haus, and Dermatological Clinic of the \\ Free University, R. Virchow Hospital, Berlin, Germany
}

\begin{abstract}
Summary
Blue and white phototherapy was given to infant (and weanling) homozygous Gunn rats treated with different doses of riboflavin5-phosphate (ribofl.5'p.) During the first hours after a flavin-injection, the effect of phototherapy with both types of fluorescent lamps was enhanced. With equal radiant power applied, the steepness of serum bilirubin decline depended on the ribofl..$^{\prime} \mathrm{p}$. dose injected. After oral or cutaneous application, no similar effect occurred. After a single flavin dose, the serum bilirubin decline lasted for at least $3 \mathrm{hr}$. Nevertheless, in long-term studies with repeated injections $(100 \mathrm{mg} / \mathrm{kg}$ every $48 \mathrm{hr})$, no protective effect beyond that of phototherapy alone could be ascertained on the Purkinje cells in the cerebella of the rats.

In the skin of the animals, fluorescence was macroscopically noticeable after ribofl. $5^{\prime}$ p. injections. When an effective irradiance of about $3.0 \mathrm{~mW} / \mathrm{cm}^{2}$ and a high flavin dose $(100-200 \mathrm{mg} / \mathrm{kg})$ was administered, histologic investigations of the skin in the abdominal and back region revealed a reversible inflammatory reaction with edema and morphologic changes in the epidermal cells that culminated 12-24 hr after the injection. After a further increase of the effective irradiance, tremendous vesicles on paws, ears, and tails were observed in most of the animals 24-72 hr after the flavin injections. The content of the blisters was primarily serous, later on, often hemorrhagic. Finally, necrosis developed.

Acute toxicity of ribofl.5'p. differed markedly when the infant rats (homozygous jaundiced as well as heterozygous nonjaundiced) were kept in the dark or under intense blue phototherapy. Much higher doses were tolerated in the dark.

Moreover, it could be demonstrated that ribofl. $5^{\circ} \mathbf{p}$. does not influence serum bilirubin of jaundiced Gunn rats kept in complete darkness. That suggests that the drug itself does not compete for albumin binding sites. But certain riboflavin ampules (Beflavin) contain stabilizers that considerably displace bilirubin from albumin bonds. Riboflavin disturbs direct photometric bilirubin measurements, but not the diazo reaction. When bilirubin is to be measured in sera containing riboflavin, lights must be extremely dim. Photodegradation in vitro is highly accelerated by the sensitizer.
\end{abstract}

\section{Speculation}

Riboflavin certainly enhances photodegradation of bilirubin. But, because the animal tests revealed serious side effects, it cannot be regarded as a safe adjunct to phototherapy in human infants.

Kostenbauder and Sanvordeker $(11,17)$ pointed out that riboflavin enhances photodegradation of bilirubin and might improve the efficiency of phototherapy in hyperbilirubinaemia in newborns. Preliminary clinical trials seemed to confirm the expected effect $(9,14)$. Because flavins must be regarded as active photosensitizers, the problem of side effects arises. Speck and coworkers $(21,22)$ and Santella et al. (16) described a DNA-modifying effect of photoactivated riboflavin (and bilirubin) in vitro and in human cells in tissue cultures. All the authors mentioned came to the conclusion that further evaluations would be necessary to ascertain the safety of riboflavin as an adjunct to phototherapy in human infants. Therefore, dose-response-relationships and side effects in Gunn rats were investigated.

\section{MATERIALS AND METHODS}

\section{DRUG-APPLICATION AND FLUORESCENT TUBES}

Infant and weanling homozygous Gunn rats received different doses $(10-200 \mathrm{mg} / \mathrm{kg})$ of the flavin mononucleotide ribofl. $5^{\prime} \mathrm{p}$. In short term studies, the tests started with one injection of ribofl. $5^{\prime} p$., which was given sc, ip, or iv, or with an application via gastric gavage, or cutaneous by bathing the infant rats in an aqueous ribofl.5'p. solution. In long-term studies, ribofl.5'p. was sc injected every $48 \mathrm{hr}$ (in a few tests, every $24 \mathrm{hr}$ ).

Immediately after the ribofl.5'p. application, the animals were either illuminated with white or special blue fluorescent tubes or kept in complete darkness. In the long-term studies, the rats remained continuously-up to 6 wk-under the same illumination.

The effective irradiance $\mathrm{E}_{\mathrm{bili}}$ of the daylight tubes (Osram L 20 $\mathrm{W} / 19$ ) was $\approx 0.3 \mathrm{~mW} / \mathrm{cm}^{2}$ and of the special blue tubes (Westinghouse F $20 \mathrm{~T} 12 / \mathrm{BB}) \approx 3.0 \mathrm{~mW} / \mathrm{cm}$. In the following text the general term "daylight or special blue" stands for these two regimens.

These types of fluorescent tubes are the ones most often used in hospitals. Effective irradiance, $0.3 \mathrm{~mW} / \mathrm{cm}^{2}$, comes close to that measured in incubators when phototherapy with a bank of daylight fluorescent tubes is given from above. With fluorescent tubes $3.0 \mathrm{~mW} / \mathrm{cm}^{2}$ can in newborn babies only be attained by doubledirection phototherapy with special blue lamps.

The shelves, cages, and the special handling of the rats were described by Ballowitz et al. (1). In this publication, a detailed definition of the spectral efficiency curve, the effective irradiance $E_{\text {bili }}$ and the radiometer used is also given. The peak sensitivity of the radiometer is at $460 \mathrm{~nm}$ (in the blue region of the spectrum) and half maximum sensitivities are at 435 and $488 \mathrm{~nm}$.

In the course of the investigations, the indication for higher effective irradiance arose. To attain $\approx 4.5 \mathrm{~mW} / \mathrm{cm}^{2}$ Philips TL 20 $\mathrm{W} / 52 \mathrm{BAM}$ blue tubes (with $20 \mathrm{~W}$ input) were selected or Westinghouse F 20 T 12/BB special blue tubes were operated with $40 \mathrm{~W}$ input. With daylight tubes (Osram L $20 \mathrm{~W} / 19$ ), an effective irradiance of $\approx 3.2 \mathrm{~mW} / \mathrm{cm}^{2}$ could only be attained by diminishing distance between tubes and cages plus $40 \mathrm{~W}$ input. On discussing these high illuminations in the second part of the article, the effective irradiance $E_{b i l i}$ will always be quoted.

\section{SERUM BILIRUBIN}

Blood was taken from the cut tail of the rats before and in fixed intervals after the injections. Direct photometric bilirubin measurements with the American Optical Bilirubinometer were com- 
pared with chemical determinations on diazo basis after Schellong's and Wende's (18) modification of the Jendrassik and Grof method. An advance test was carried out to check on bilirubin measuring the influence of ribofl.5'p. and of its photoproductsoriginating after in vitro illumination in the presence of oxygen.

\section{CHEMICALS}

For the main tests, pure ribofl.5'p. substance (LaRoche) was dissolved under dim lights in sterile distilled water and, immediately thereafter, injected into the animals. For orientation, Beflavin ampules (La Roche) were used in a few experiments. Besides riboflavin, these ampules contain as stabilizers Nipagin/ Nipasol, $\mathrm{Na}$ hydrogen phosphate, $\mathrm{Na}$ oxy-methoxybenzoate. (The concentration of the different substances was not declared by the manufacturers).

\section{ACUTE TOXICITY}

Following the method of Behrens and Kärber (3), $\mathrm{LD}_{50}$ of ribofl.5'p. (and of Beflavin) was determined in the dark, under daylight, or special blue phototherapy in homozygous (jaundiced) as well as in heterozygous (nonjaundiced) 3- to 5-day-old Gunn rats.

\section{KERNICTERUS GRADING}

Histochemical staining of oxidative enzymes LDH, SDH, and $\mathrm{NaDH}_{2}$-Tetrazolium reductase in the Purkinje cells of the cerebellum $(2,8)$ uncovers the nerve cell loss by bilirubin encephalopathy. These investigations were carried out after repeated injections of ribofl.5'p. or of saline dummy injections in illuminated and nonilluminated animals.

\section{EXAMINATIONS OF THE SKIN}

After ribofl.5'p. injections, the degree and duration of fluorescence in the skin was macroscopically noticed and so was the formation of vesicles and areas of necrosis on paws, tails, and ears.

For histologic investigations, skin sections were prepared from the abdominal and back region, and the PAS (periodic acid Schiff) reaction as well as the hematoxylin-eosin stainings were compared. Furthermore, vesicles and areas of necrosis on paws, tails, and ears were examined with the light- and the electronmicroscope.

\section{RESULTS AND DISCUSSION}

Only the main data and conclusions will be given. Details can be taken from the theses of Bunjamin (4), Lietz (12), and Wirjadi (23).

\section{SERUM BILIRUBIN}

Methodical particularities. In general, serum bilirubin concentration of Gunn rats as well as of human infants can be precisely measured with the American Optical Bilirubinometer. This instrument is designed to indicate the light transmission through the serum specimen at $461 \mathrm{~nm}$ - the absorption peak of bilirubinand simultaneously at $551 \mathrm{~nm}$. Internal subtraction of the absorption at $551 \mathrm{~nm}$ from that at $461 \mathrm{~nm}$ offsets the absorption by hemoglobin in moderately hemolytic sera.

Direct photometric bilirubin measurements with the American Optical Bilirubinometer proved disturbed by riboflavin which has a maximum absorption at $450 \mathrm{~nm}$. Its absorption slope obviously comes into the $460 \mathrm{~nm}$ region. Figure 1 shows kind of a calibration for ribofl.5'p. on this instrument. Remarkable deviations are to be expected with high ribofl.5'p. contents.

With the chemical method on diazo basis, no such disturbances occurred. In vitro addition of ribofl.5'p. to sera of homo- or of heterozygous Gunn rats had no influence on the bilirubin value measured on diazo basis. The same was true when (instead of a fresh ribofl.5'p. solution) the photo-products, which originated during illumination of an aqueous ribofl.5'p. solution in the presence of oxygen in vitro, were added.

For our main investigation, therefore, this method was used.

Utmost care was necessary to shield off lights when measuring bilirubin in sera containing riboflavin. In the presence of flavin and light, bilirubin concentration decreased much faster than in solutions containing bilirubin only.

\section{SERUM BILIRUBIN AFTER RIBOFLAVIN APPLICATION IN THE DARK}

Ribofl.5'p. does not significantly influence serum bilirubin in complete darkness, neither in vitro nor in vivo. Figure $2 \mathrm{~b}$ demonstrates the mean serum bilirubin in 3- to 5-day-old rats before, 30 $\mathrm{min}, 3 \mathrm{hr}$, and $24 \mathrm{hr}$ after sc injection of 100 or $200 \mathrm{mg} / \mathrm{kg}$ ribofl.5' $\mathrm{p}$. Figure $3 \mathrm{~b}$ gives the same data in 1-month-old rats. From this observation, it may be concluded that ribofl.5'p. itself does not considerably compete with bilirubin for albumin binding sites. Injections of other compounds, which do strongly compete (sulfonamides or benzoates for instance), induce a sharp decline in the serum bilirubin concentration of Gunn rats. The displaced bilirubin equilibrates with other compartments.

Such a decline occurred when, instead of ribofl.5'p. solution, Beflavin ampules were used which contain benzoate stabilizers. Thirty min after sc injection of $2 \mathrm{ml} / \mathrm{kg}$ Beflavin $(=10 \mathrm{mg} / \mathrm{kg}$ riboflavin) or of $2 \mathrm{ml} / \mathrm{kg}$ of the stabilizer alone (LaRoche supplied us with this special preparation, without riboflavin) serum bilirubin in 3- to 5-day-old homozygous Gunn rats dropped to 55-60\% of the starting level and remained there for more than $3 \mathrm{hr}$. Even $24 \mathrm{hr}$ later, the starting level was not reached again. Obviously, the stabilizer displaced bilirubin from the plasma albumin bonds.

\section{SERUM BILIRUBIN AFTER PHOTOTHERAPY}

Figure $2 \mathrm{a}$ demonstrates the effect of daylight and special blue phototherapy alone-without flavin injections-in 3- to 5-day-old rats, and Figure $3 \mathrm{a}$ the same in 1-month-old rats.

These and the following diagrams represent the mean results of serial measurements of serum bilirubin concentrations. The starting level is taken as 100 and the levels obtained during the illumination are expressed in percent of this starting level. SD are not marked on the curves for graphical reasons and because of the

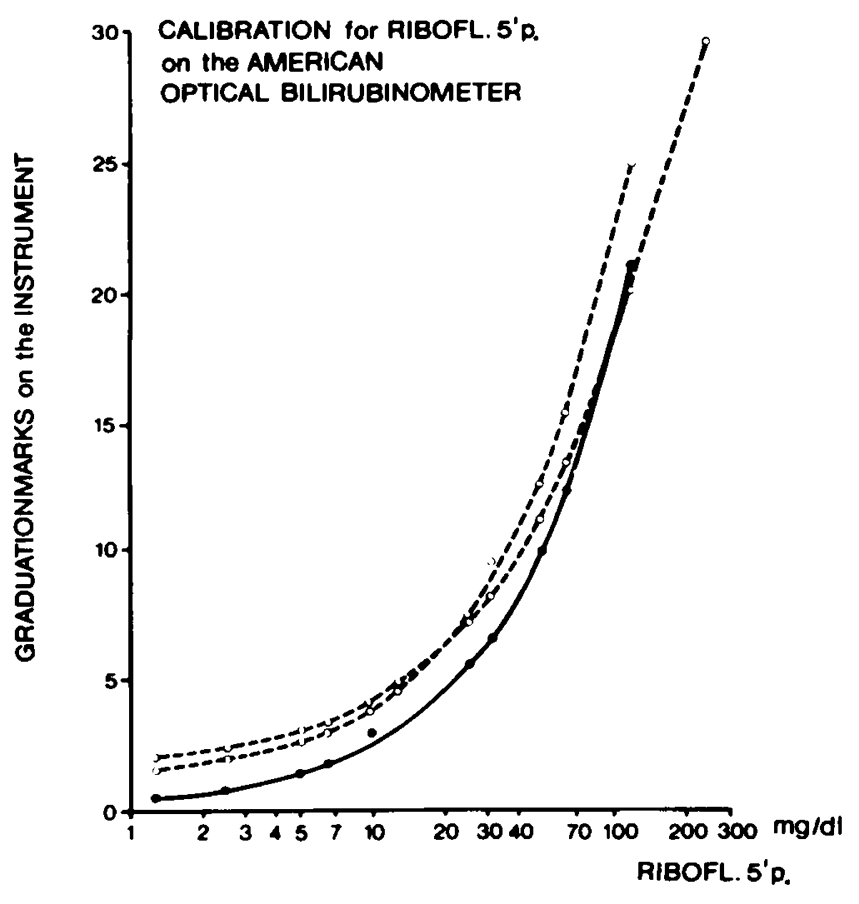

Fig. 1. Calibration curve for ribofl.5'p. on the American Optical Bilirubinometer. - in rat serum -...-- in distilled water. 
SERUMBILIRUBIN in \% of the starting level

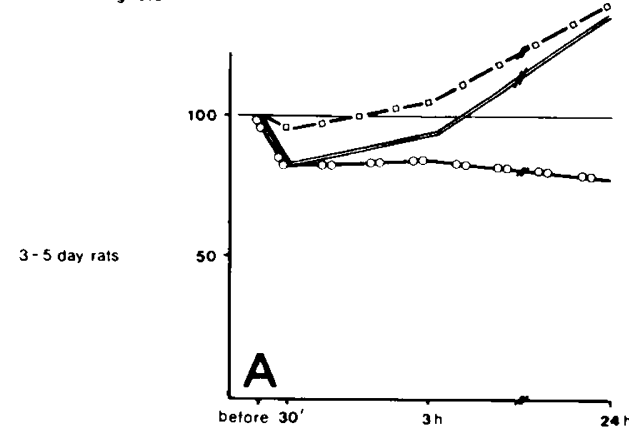

$$
\begin{array}{llll}
\text { No of animals } & & \\
\text { dark } & 0 & 14 & 14 \\
\text { daylight } & 18 & 18 \\
\text { specral blue } & 00-\infty-\infty & 10 & 10
\end{array}
$$

$\begin{array}{cc}14 & 14 \\ 18 & 18 \\ 9 & 9\end{array}$

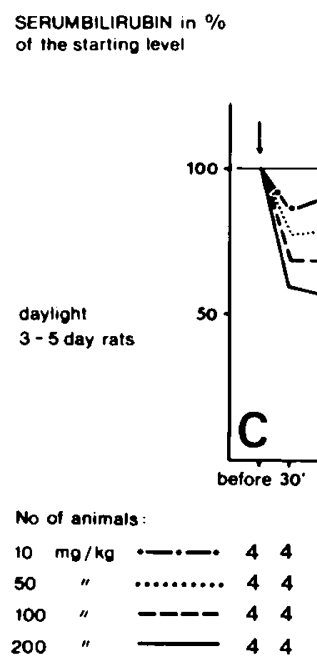

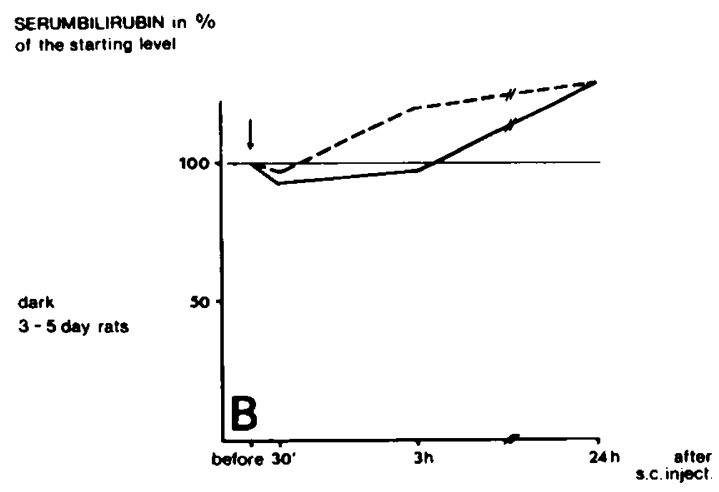

No of animals :

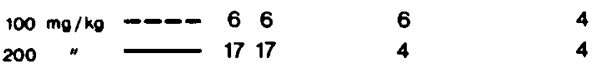

SERUMBILIRUBIN in \%

\begin{tabular}{|c|c|c|c|c|c|c|}
\hline \multirow[b]{2}{*}{10} & & \multicolumn{4}{|c|}{ No of animals: } & \\
\hline & $\mathrm{mg} / \mathrm{kg}$ & -二・- & & 4 & 4 & 4 \\
\hline 50 & $"$ & .......... & 5 & 5 & 5 & 5 \\
\hline 100 & $"$ & $--\infty$ & 4 & 4 & 4 & 4 \\
\hline 200 & $"$ & & 4 & 4 & 4 & 4 \\
\hline
\end{tabular}
of the starting level

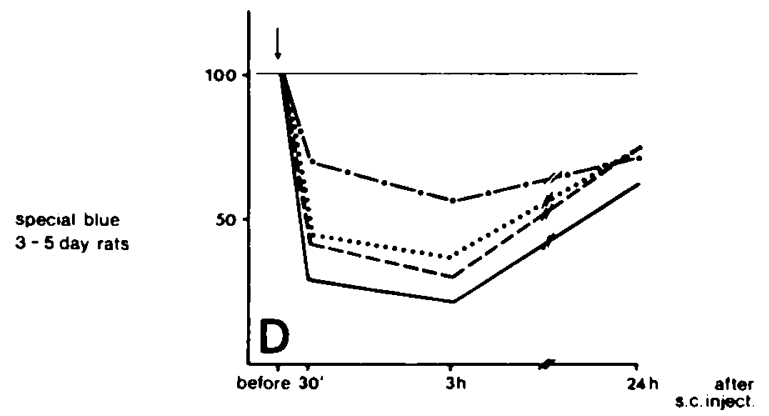

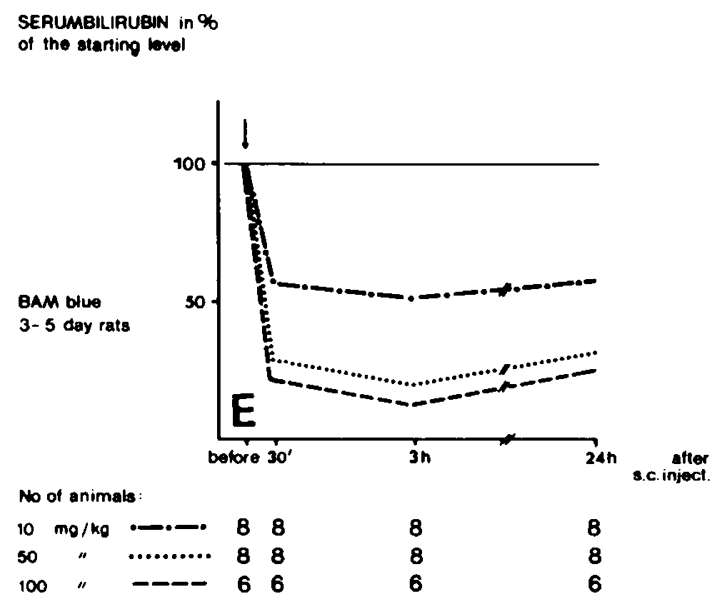

Fig. 2. $A$ Serum bilirubin curves in 3- to 5-day old homozygous Gunn rats in the dark, or under daylight $\left(\mathrm{E}_{\text {bili }} 0.3 \mathrm{~mW} / \mathrm{cm}^{2}\right)$, or special blue $\left(\mathrm{E}_{\text {bili }} 3.0\right.$ $\left.\mathrm{mW} / \mathrm{cm}^{2}\right)$ phototherapy without any injections. B-E Changes of the mean serum bilirubin concentration in 3- to 5-day old homozygous Gunn rats after s.c. ribofl.5'p. injections $B$ ) animals kept in practically complete darkness, $C$ ) animals kept under daylight illumination; $\mathrm{E}_{\text {hili }} 0.3 \mathrm{~mW} / \mathrm{cm}^{2}, D$ ) animals kept under special blue illumination. $E_{\text {hili }} 3.0 \mathrm{~mW} / \mathrm{cm}^{2} E$ ) animals $k e p t$ under $B A M$ blue illumination $E_{\text {hili }} 4.5 \mathrm{~mW} / \mathrm{cm}^{2}$.

small numbers in some animal groups. Table 1 gives the appropriate data in $\mathrm{mg} / \mathrm{dl}$ for Figures $2 \mathrm{a}$ and $3 \mathrm{a}$.

Proceeding from each single animal, analyses of SD and SEM were done on the percent basis. In all groups, SEM of the difference in serum bilirubin between start and $30 \mathrm{~min}$ revealed $3-4 \%$, between start and $3 \mathrm{hr}, 5-7 \%$, and between start and $24 \mathrm{hr}$,
5-9\%. In all groups of animals that were injected with ribofl.5'p., the $30 \mathrm{~min}$ and $3 \mathrm{hr}$ values differed from the starting level with the same trend; i.e., a serum bilirubin decline. This allows to use the one-tailed $t$-test, and a $30 \mathrm{~min}$ difference in the curves of $6-8 \%$ and a $3 \mathrm{hr}$ difference of $10-14 \%$ can be regarded as significant $(P$ $<0.05)$. 
SERUMBILIAUBIN in $\%$ of the starting level
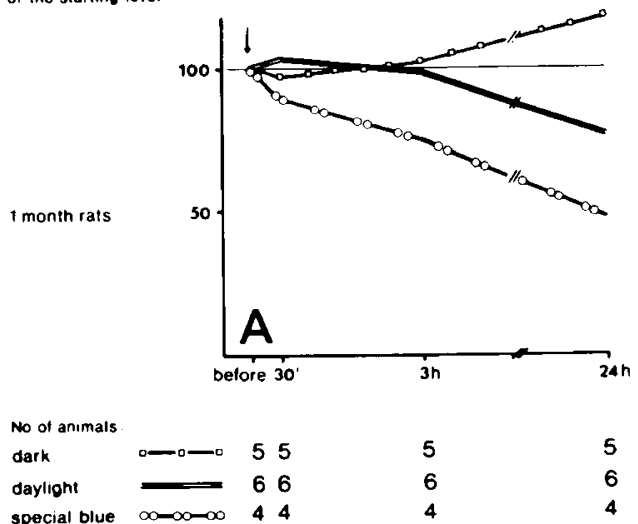

SERUMBILIPUBIN in \% of the starting level

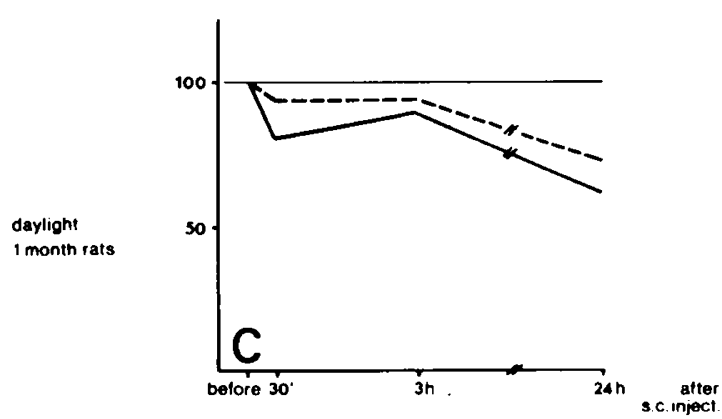

No of animals:

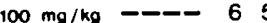

100

$\begin{array}{ll}5 & 5 \\ 6 & 6 \\ 4 & 4\end{array}$

SERUMBILIRUBIN in \% of the starting level

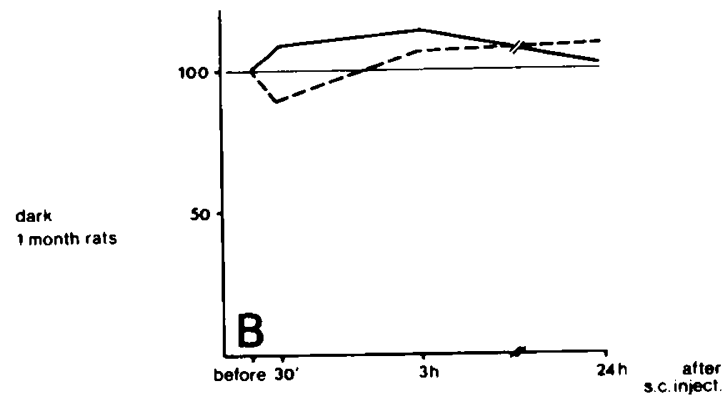

No of animals:

$\begin{array}{lllll}100 \mathrm{mg} / \mathrm{kg} & 6 & 6 & 6 & 6 \\ 200 " & 66 & 6 & 6\end{array}$

SERUMBILIRUBIN in \% of the starting level

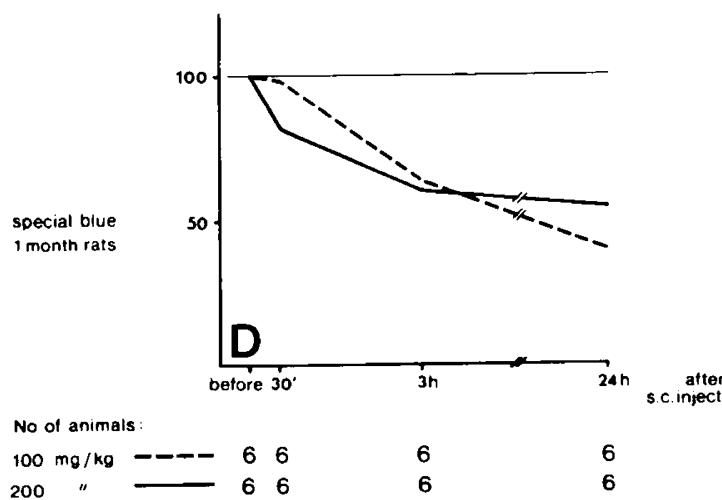

Fig. 3. $A$ Serum bilirubin curves in 1 month old homozygous Gunn rats in the dark or under daylight $\left(\mathrm{E}_{\text {hili }} 0.3 \mathrm{~mW} / \mathrm{cm}^{2}\right)$ or special blue phototherapy $\left(\mathrm{E}_{\mathrm{hili}} 3.0 \mathrm{~mW} / \mathrm{cm}^{2}\right)$ without any injections. $B-D$ Changes of the mean serum bilirubin concentration in 1-month old homozyogous Gunn rats after s.c. ribofl.5'p. injections; $B$ ) animals kept in practically complete darkness, $C$ ) animals kept under daylight illumination; $\mathrm{E}_{\mathrm{bili}} 0.3 \mathrm{~mW} / \mathrm{cm}^{2}, D$ ) animals kept under special blue illumination; $E_{\text {bili }} 3.0 \mathrm{~mW} / \mathrm{cm}^{2}$.

Table 1. Serum bilirubin concentration in $\mathrm{mg} / \mathrm{dl}+S D$ in animals receiving phototherapy, but no ribofl. $5^{\prime} \mathrm{p}^{1}$

\begin{tabular}{|c|c|c|c|c|c|}
\hline Age & Illumination & $\begin{array}{c}\text { Level before illumina- } \\
\text { tion }\end{array}$ & after $30 \mathrm{~min}$ & after $3 \mathrm{hr}$ & after $24 \mathrm{hr}$ \\
\hline \multirow[t]{3}{*}{ 3-5 days } & $\begin{array}{l}\text { Controls in the } \\
\text { dark }\end{array}$ & $6.1 \pm 1.3$ & $6.0 \pm 1.1$ & $6.5 \pm 1.2$ & $8.5 \pm 1.0$ \\
\hline & Daylight & $6.2 \pm 1.4$ & $5.1 \pm 1.4$ & $5.7 \pm 1.5$ & $8.4 \pm 0.9$ \\
\hline & Special blue & $6.5 \pm 1.8$ & $5.4 \pm 1.4$ & $5.6 \pm 1.4$ & $5.1 \pm 1.4$ \\
\hline \multirow[t]{3}{*}{1 month } & $\begin{array}{l}\text { Controls in the } \\
\text { dark }\end{array}$ & $5.8 \pm 0.6$ & $5.7 \pm 0.6$ & $6.0 \pm 0.6$ & $6.8 \pm 0.7$ \\
\hline & Daylight & $5.4 \pm 1.2$ & $5.6 \pm 1.0$ & $5.3 \pm 1.1$ & $4.1 \pm 1.2$ \\
\hline & Special blue & $5.4 \pm 1.4$ & $4.8 \pm 0.8$ & $4.0 \pm 1.0$ & $2.5 \pm 0.9$ \\
\hline
\end{tabular}

' For number of animals see Figures 2a and 3a.

Compared to 3- to 5-day-old rats (without fur), the serum bilirubin decline by phototherapy alone is steeper in 1-month-old rats (special blue $3 \mathrm{hr}, P<0.05,24 \mathrm{hr}, P<0.01$, daylight $24 \mathrm{hr}$, $P<0.01)$ despite the fact that the older rats have a fairly thick fur, and hair must be regarded as a light trap. This can only be explained by the fact that bilirubin metabolism is in a steady state in 1-month-old rats, whereas in the infant rats, it is not so. Serum bilirubin of 3- to 5-day-old rats physiologically rises.

\section{INFLUENCE OF ONE SINGLE RIBOFL.5'P. DOSE ON THE PHOTOTHERAPY EFFECT}

In Figure 2c-e, mean serum bilirubin of 3- to 5-day-old rats receiving different doses of ribofl.5'p. sc under different irradiance daylight (Osram L $20 \mathrm{~W} / 19 \mathrm{E}_{\text {bili }} 0.3 \mathrm{~mW} / \mathrm{cm}^{2}$ ), special blue (Westinghouse F $20 \mathrm{~T} / 12 \mathrm{BB} \mathrm{E}_{\text {bili }} 3.0 \mathrm{~mW} / \mathrm{cm}^{2}$ ), and Bam blue (Philips TL $20 \mathrm{~W} / 52 \mathrm{E}_{\text {bili }} 4.5 \mathrm{~mW} / \mathrm{cm}^{2}$ ) is plotted. For 1 -monthold rats, corresponding data are given in Figures $3 \mathrm{c}$ and $\mathrm{d}$.

In light-exposed animals receiving ribofl.5'p., serum bilirubin decreases not only in relation to the injected ribofl.5'p. dose, but also to the amount of effective irradiance applied. The flavin effect is significantly more marked in infant than in 1-month-old rats.

In Figure $2 \mathrm{c}$, the $30 \mathrm{~min}$ and $3 \mathrm{hr}$ difference in serum bilirubin concentration between the four doses used is greater than $10 \%(P$ $<0.05$ ). The same is true for three of the four curves in Figure $2 \mathrm{~d}$ and for 2 of the 3 curves in Figure 2e. Taking $100 \mathrm{mg}$ ribofl.5'p. 
as a basis, it is easy to recognize that the different enhancement of bilirubin decline by the three types of lamps distinctly surpasses 10\% $(P<0.05)$.

In contrast to Kostenbauder and Sanvordeker (11), enhancement of bilirubin photo-decay by injected ribofl.5'p. under white as well as under special blue lights was observed in this study. These authors used shaved adult Gunn rats for their experiments and only saw an effect of the flavin in combination with daylight phototherapy of low effective irradiance ( 300 foot candles), but not when 750-1100 foot candles were applied. In the latter group, serum bilirubin rapidly declined with phototherapy alone.

With the exception of the low ribofl.5'p. doses under daylight the deepest fall in serum bilirubin concentration in 3- to 5-day-old rats (Figs. 2c-e) was measured $3 \mathrm{hr}$ after the sc injection. Twentyfour hr after the injections, serum bilirubin under daylight is in the same range as with phototherapy alone, and it is almost so with special blue. Only after 50 or $100 \mathrm{mg} / \mathrm{kg}$ ribofl.5'p. sc and 24 hr BAM blue illumination $\left(E_{\text {bili }} 4.5 \mathrm{~mW} / \mathrm{cm}^{2}\right)$ is the serum bilirubin concentration in infant rats still markedly lower than with BAM blue phototherapy alone.

The overall enhancement of phototherapy by sc injected ribofl.5'p. is distinctly lower in 1-month-old rats. The early decline is comparably small (Figs. 3c and d). From other comparisons between these two age groups of rats (Goebel), it can be assumed that this is due mainly to delayed equilibration of ribofl.5'p. between skin and blood in the older ones.

Half life of ribofl.5'p. in the blood of the rats is short. Christensen (5) indicates $12 \mathrm{~min}$. as t/2 of the disappearance rate and $26 \mathrm{~min}$. as $t / 2$ of urinary excretion. This may explain that between 3 and $24 \mathrm{hr}$ after the injection, serum bilirubin concentration in infant rats increases again, even when phototherapy is continued. It is here where our results differ from studies on photosensitized Gunn rats reported by McDonagh (13) using hematoporphyrin as a sensitizer instead of riboflavin. In his experiments, the pronounced drop in serum bilirubin induced by porphyrin plus light continued up to $24 \mathrm{hr}$ even when the lights were turned off $6 \mathrm{hr}$ after the porphyrin injection. Half-life time of hematoporphyrin is long and in contrast to riboflavin, porphyrins become concentrated in the basal layers of the dermis (15). In the skin of human beings, hematoporphyrin is demonstrable for at least 4 wk after one iv injection (10).

Serum bilirubin decline after ip and iv injection of ribofl. $5^{\prime} p$. was not very different from that seen after sc injections. In infant rats, the initial slope turned out somewhat steeper, so that the lowest value was already reached $30 \mathrm{~min}$ after ip or iv application, followed by a plateau or a slight increase between $30 \mathrm{~min}$ and 3 hr. The 3-hr levels were nearly equal after sc, ip, or iv injection. Serum bilirubin of 1-month-old rats illuminated with special blue tubes also showed a somewhat more pronounced decline after ip than after sc application, but the difference was not statistically significant.

The authors were unable to demonstrate any effect of ribofl.5'p. on the serum bilirubin concentration in illuminated infant rats after oral (up to $2000 \mathrm{mg} / \mathrm{kg}$ ) or cutaneous application of an aqueous solution of the flavin.

\section{SERUM BILIRUBIN IN LONG-TERM STUDIES}

In long-term studies, $100 \mathrm{mg} / \mathrm{kg}$ ribofl.5' $\mathrm{p}$. or saline dummy injections were sc administered every $48 \mathrm{hr}$. Serum bilirubin concentration was determined before every 2 nd injection. At that time, there was probably no more ribofl.5'p. left in the animal. The results are given in Figure 4. Under special blue lights, no difference could be ascertained between ribofl.5'p. injected animals and the control group. Under white lights and in the dark (In this experimental series, some room lighting reached the animals during handling and blood sampling), the riboflavintreated group showed lower serum bilirubin between days 9-25 than the saline-treated group. The difference is about $2 \mathrm{mg} / \mathrm{dl}$ in the 3rd wk and diminishing thereafter with increasing age parallel to the development of the fur and the physiologic bilirubin decline.

\section{KERNICTERUS GRADING}

Histochemical staining of the Purkinje cells in the cerebellum was carried out after repeated sc injections of $100 \mathrm{mg} / \mathrm{kg}$ ribofl.5' $\mathrm{p}$. or dummy injections and different illumination. Bilirubin inhibits the activity of oxidative and glycolytic enzymes. Affected Purkinje cells do not show up any more in the sections (8).

The results of the long-term studies with 13-28 injections are summarized in Table 2 (No blood for bilirubin measuring was taken from these rats).

A significant difference between ribofl.5'p.-injected and control rats (with saline dummy injections) could not be ascertained either in the animals kept in the dark or in the illuminated groups. It was obvious that special blue light illumination provided a pronounced protection, so that probably no further improvement by the ribofl.5'p. photosensitisation was possible. However, even in the animals receiving low intensity phototherapy with daylight tubes, the loss of Purkinje cells was not significantly reduced by ribofl.5'p.

\section{FLUORESCENCE OF THE SKIN AND THE URINE}

About 5-10 min after sc injection of ribofl.5'p. into infant rats, fluorescence, which initially appears around the site of the injection, is already macroscopically noticeable on the whole body of the animal (We did not carry through special measurements of the excitement). After a sc dose of $200 \mathrm{mg} / \mathrm{kg}$, it lasts under special blue illumination for about 3-4 hr, after ip or iv injection, about 2-3 hr. Under daylight, it can be seen for about 6-7 hr after sc and up to $6 \mathrm{hr}$ after iv or ip application.

In 1-month-old rats, fluorescence is less impressive. Immediately after iv injection, the phenomenon was perceived on the hairless ears, the paws, and the snout. The peak was between 10 and 30 min, and it disappeared by 1 to $1 \frac{1 / 2}{h r}$. There was no great difference under special blue or daylight. The first color change after sc injection could only be seen after 20 min. It was distinctly less pronounced than after iv injection.
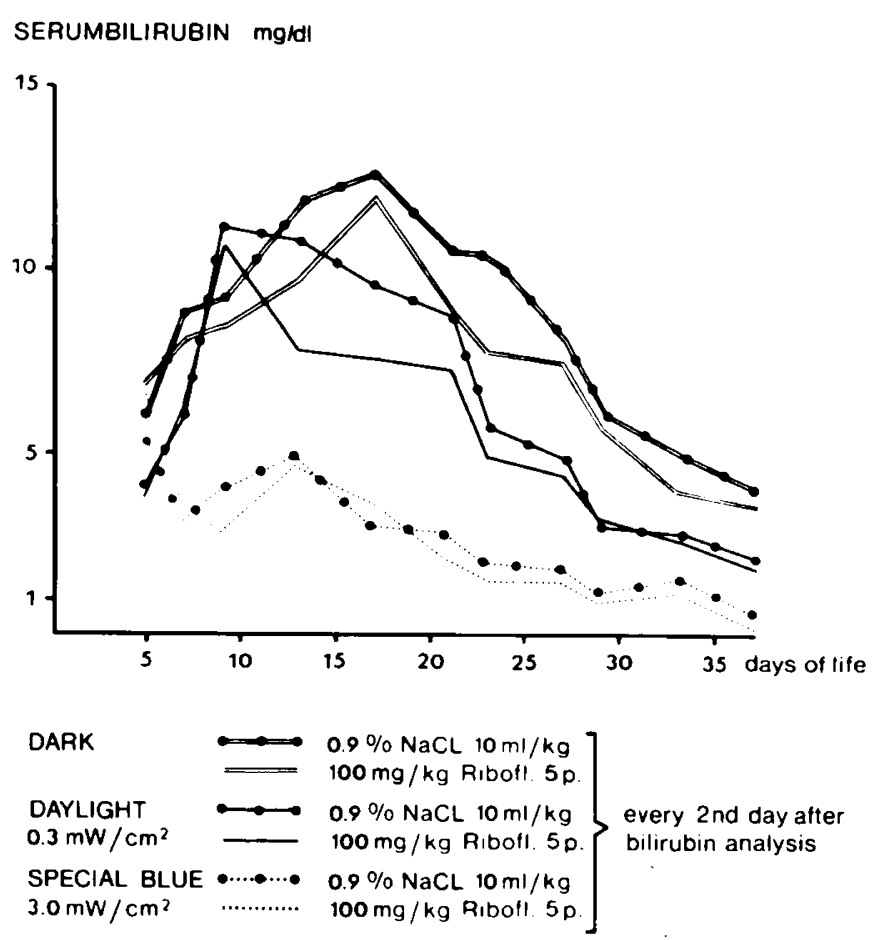

Fig. 4. Changes in the mean serum bilirubin concentration during long-term studies in homozygous Gunn rats receiving ribofl.5'p. or saline dummy s.c. injections every $48 \mathrm{hr}$. (In these long-term studies some lights reached the animals in the dark during handling). Each group covered 4 animals at the start (during the 3rd wk two ribofl.5'p. injected rats died under special blue, and two in both groups in the dark. SD did not exceed $7.2 \mathrm{mg} / \mathrm{dl}$ ). 
A yellowish color and fluorescence was noticeable in the urine about 3-5 min after iv or ip injection, and about $10 \mathrm{~min}$ after sc injection of $200 \mathrm{mg} / \mathrm{kg}$. The excretion lasted for more than $10 \mathrm{hr}$ in infant as well as in 1-month-old rats.

\section{HISTOLOGIC INVESTIGATIONS OF THE SKIN FROM THE ABDOMINAL AND BACK REGION}

Periodic acid-Schiff (PAS) and hematoxylin-eosin stainings of skin sections from the abdominal and back region were carried out only after sc injections with daylight, special blue, or no illumination at all. Only when under special blue illumination, a high dose $(100-200 \mathrm{mg} / \mathrm{kg})$ ribofl.5'p. was given, a reversible phototoxic reaction revealed with edema and morphologic changes in the epidermal cells, i.e., positive intracellular PAS reactions, a tendency to pyknosis of the nuclei and blurred contours of the cells. No equivalents could be seen in animals receiving the same ribofl.5'p. dose, but being kept in the dark or under daylight phototherapy. The skin lesions under special blue lights were found in homozygous jaundiced animals as well as in het-

Table 2. Kernicterus grading

\begin{tabular}{|c|c|c|c|c|c|c|c|c|c|c|c|c|c|c|c|c|c|c|}
\hline \multirow{3}{*}{ Illumination } & \multirow{2}{*}{\multicolumn{6}{|c|}{ Special blue }} & \multirow{2}{*}{\multicolumn{6}{|c|}{ Daylight }} & \multirow{2}{*}{\multicolumn{6}{|c|}{ None (dark) }} \\
\hline & & & & & & & & & & & & & & & & & & \\
\hline & \multicolumn{6}{|c|}{ Ribofl.5'p./saline } & \multicolumn{6}{|c|}{ Ribofl.5'p./saline } & \multicolumn{6}{|c|}{ Ribofl.5'p./saline } \\
\hline Purkinje cell status & $g^{1}$ & $t^{2}$ & $++t^{3}$ & $\varnothing$ & + & $++t$ & $\varnothing$ & + & +++ & $\varnothing$ & + & +++ & $\varnothing$ & + & +++ & $\varnothing$ & + & +++ \\
\hline No. of animals & 3 & 10 & 0 & 4 & 8 & 1 & 0 & 11 & 7 & 1 & 8 & 5 & 2 & 5 & 5 & 0 & 3 & 6 \\
\hline
\end{tabular}

Table 3. Blister reactions on the acra

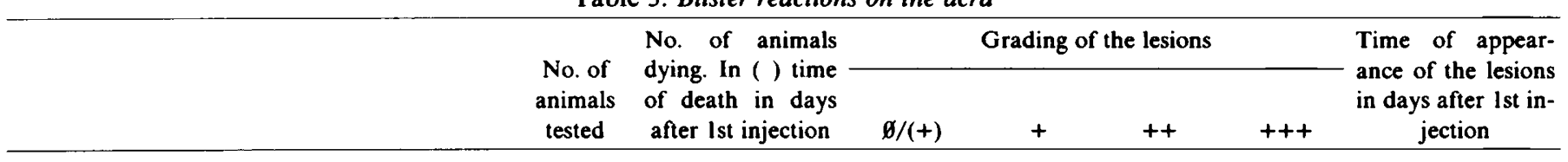

Westinghouse special blue $20 \mathrm{~W}$

Effective irradiance $\approx 3.0 \mathrm{~mW} / \mathrm{cm}^{2}$

Ribofl.5'p. dose

$3 \times 50 \mathrm{mg} / \mathrm{kg}^{1}$
$1 \times 100 \mathrm{mg} / \mathrm{kg}^{\prime}$
$3 \times 100 \mathrm{mg} / \mathrm{kg}^{1}$
$1 \times 200 \mathrm{mg} / \mathrm{kg}$

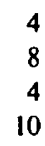

Westinghouse special blue $40 \mathrm{~W}$

Effective irradiance $\approx 4.5 \mathrm{~mW} / \mathrm{cm}^{2}$

$$
\begin{aligned}
& (2-) 3 \times 50 \mathrm{mg} / \mathrm{kg}^{\prime} \\
& 1 \times 100 \mathrm{mg} / \mathrm{kg}
\end{aligned}
$$

(2-) $3 \times 100 \mathrm{mg} / \mathrm{kg}^{1}$

$1 \times 200 \mathrm{mg} / \mathrm{kg}$

12

16

12

Philips BAM blue $20 \mathrm{~W}$

Effective irradiance $\approx 4.5 \mathrm{~mW} / \mathrm{cm}^{2}$

$$
10 \times 10 \mathrm{mg} / \mathrm{kg}^{2}
$$

$5 \times 50 \mathrm{mg} / \mathrm{kg}^{\prime}$

$1 \times 100 \mathrm{mg} / \mathrm{kg}$

$(2-) 3 \times 100 \mathrm{mg} / \mathrm{kg}^{\prime}$

$1 \times 200 \mathrm{mg} / \mathrm{kg}$

Osram daylight $40 \mathrm{~W}$

Effective irradiance $\approx 3.2 \mathrm{~mW} / \mathrm{cm}^{2}$

$$
\begin{aligned}
& 1 \times 100 \mathrm{mg} / \mathrm{kg}^{1} \\
& 2 \times 100 \mathrm{mg} / \mathrm{kg}^{1}
\end{aligned}
$$$$
1 \times 200 \mathrm{mg} / \mathrm{kg}^{1}
$$

$$
\begin{gathered}
1 \\
(<1) \\
1 \\
(<1) \\
16
\end{gathered}
$$$$
(<1)
$$

$$
4
$$$$
2
$$

$(<1-1)$

\section{5}

(n-

1

$\begin{array}{rrr}2 & 4 & 2-4 \\ 3 & 11 & 1-4 \\ 6 & 5 & 2-3\end{array}$

2

2
1

(9)

1

(3)

(8-9)

10
6

(1)

2

$\begin{array}{ccc}5 & 1 & 2-3 \\ 11 & 4 & \begin{array}{c}(1 \times 6) \\ 1-2\end{array} \\ 1 & 21 & 1-3 \\ & & (1 \times 4) \\ 1 & 11 & 1-2\end{array}$

'Injections given every $48 \mathrm{hr}$.

${ }^{2}$ Injections, $10 \mathrm{mg} / \mathrm{kg}$, given every $24 \mathrm{hr}$. 
erozygous nonjaundiced rats. The inflammatory reactions culminated between 12 and $24 \mathrm{hr}$ after the injection.

When under continuous special blue illumination, 10-20 injections of $100 \mathrm{mg} / \mathrm{kg}$ were administered in intervals of $48 \mathrm{hr}$, no skin reactions could be demonstrated in the abdominal or back region of the animals. At the time of the investigation, the rats were 1-month-old or older and had a thick fur. In 2 of 10 animals, which repeatedly received $100 \mathrm{mg} / \mathrm{kg}$ under special blue lights, vesicles and areas of necrosis appeared on the paws and the tail. Morphology of the alterations could be regarded as typical for phototoxic reactions in rodents (24). This last observation induced-as mentioned previously-the additional tests with the rather high irradiance of $3.2-4.5 \mathrm{~mW} / \mathrm{cm}^{2}$.

\section{PHOTOTOXIC REACTIONS ON PAWS, TAILS, AND EARS}

When an effective irradiance of more than $3 \mathrm{~mW} / \mathrm{cm}^{2}$ was employed and as an adjunct $100-200 \mathrm{mg} / \mathrm{kg}$ ribofl.5'p. sc characteristic lesions appeared in high frequency on the acra. Details are listed in Table 3. The vesicles developed 1-4 days after the ribofl.5'p. injections under continuous illumination. They equally

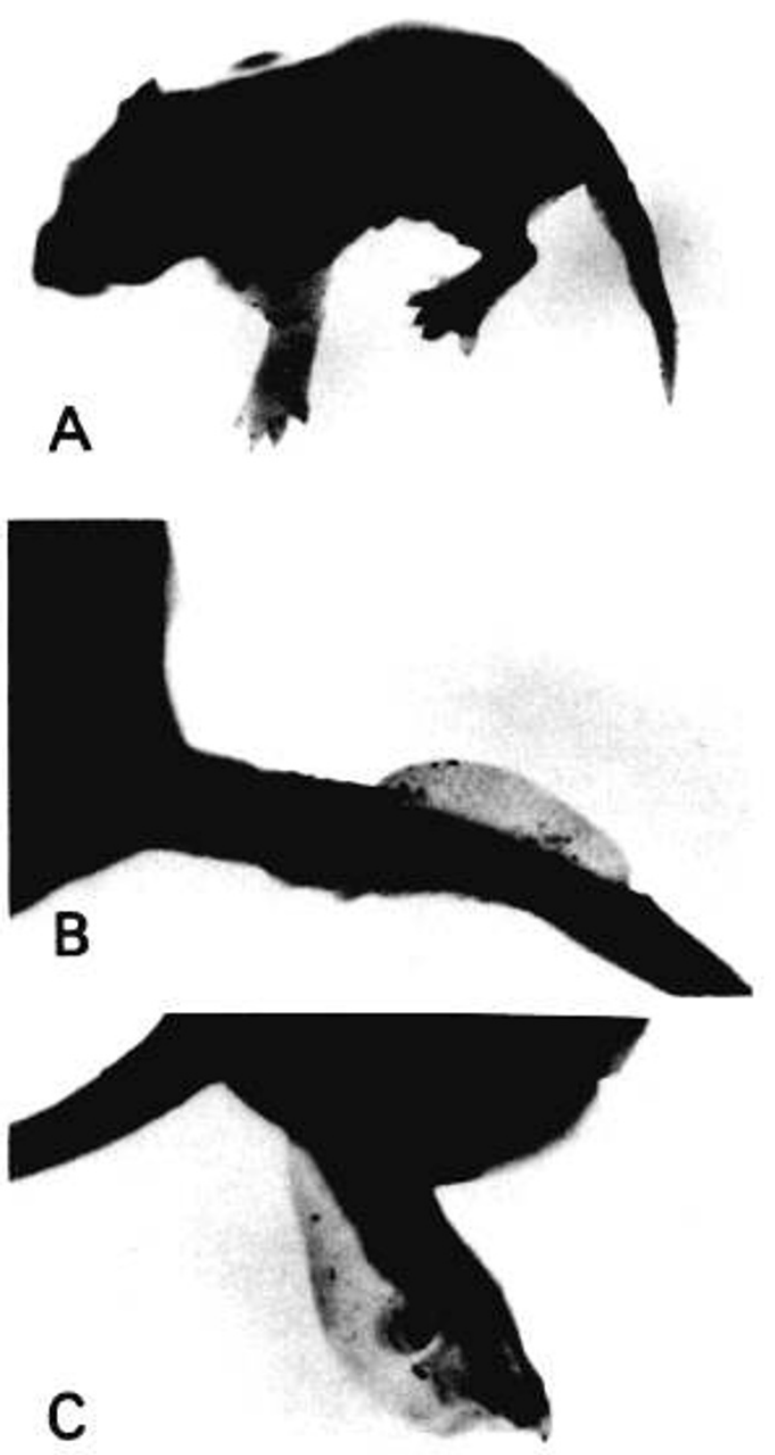

Fig. 5. $A-C$ Blisters on paws and tails, which developed after s.c. injection of $100-200 \mathrm{mg} / \mathrm{kg}$ ribofl.5' $\mathrm{p}$. in infant Gunn rats illuminated with an effective irradiance of more than $3.0 \mathrm{~mW} / \mathrm{cm}^{2}$. appeared in homozygous and in heterozygous infant rats. Many of the animals receiving $200 \mathrm{mg} / \mathrm{kg}$ ribofl.5'p. sc died within a few hr becoming adynamic, hypotonic, and anuric (the few drops of urine which still could be emptied were intensely yellowishfluorescent). These animals did not (yet) show skin lesions. No such reactions on the acra occurred in animals kept under the same lights but receiving dummy injections. There were no striking differences between the different tubes used. Obviously, the high amount of effective irradiance turned the scale. Figure $5 \mathrm{a}-\mathrm{c}$ are photographs of particularly severe lesions. In general, the content of the vesicles on paws and tails was initially serous. In those animals, which received a second ribofl.5'p. dose $48 \mathrm{hr}$ after the first one, the liquid in the vesicles got intensely yellowish and more fluorescent than the surrounding skin a few min after the second application. Especially at the ears, the vesicles soon became hemorrhagic. Four to six days after appearing, the blisters dried up, leaving parts of the toes, of the ears, and of the tails necrotic (Fig. 6). The general condition of the animals had to be marked as bad. All these rats were killed.

\section{HISTOLOGIC INVESTIGATIONS OF THE BLISTERS}

Serial sections mainly from tails were investigated. Unlike paws, the tails needed no bone-decalcification. Figure $7 b+c$ represent the typical features. Probably as a result of permeability changes in the blood vessels, massive perivascular edema were developing. Increased interstitial fluid that pressed against the epidermis formed blisters in the subepidermal space lifting the epidermis from the corium. Stratum basale cells appeared swollen and acantholytic. Morphologically, it was impossible to decide, whether an additional loosening of the epidermis-caused by phototoxic substances-had occurred. As for the necrotic parts, vasculitis and fibrinoid necrosis could clearly be recognized (Fig. 8).

\section{MORTALITY (LDS0)}

In homozygous as well as in heterozygous infant Gunn rats, acute toxicity of ribofl.5'p. differed markedly when the animals were kept under intense blue phototherapy or remained in the dark. Under special blue lights $70-90 \%$ of heterozygous infant rats receiving $200 \mathrm{mg} / \mathrm{kg}$ ribofl.5'p. sc died within 1-4 days, whereas $600 \mathrm{mg} / \mathrm{kg}$ were tolerated by all animals kept in the dark or under daylight illumination with an effective irradiance of $0.3 \mathrm{~mW} / \mathrm{cm}^{2}$.

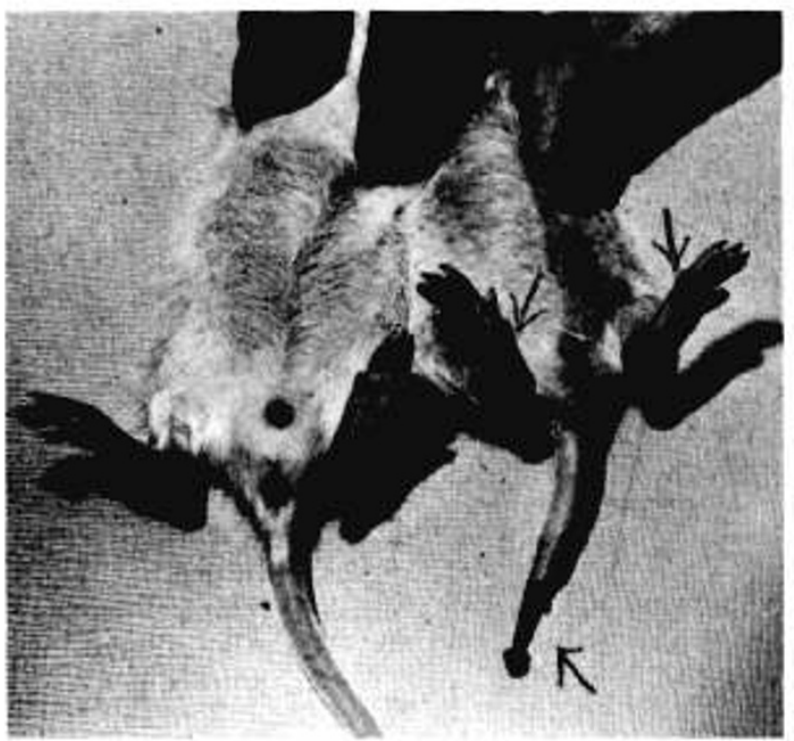

Fig. 6. Necrosis at the tip of the tail $\uparrow$ and at the sole $\uparrow$ (on the left hand control animal without such lesions). 
Fifty\% of the 3- to 5-day-old rats in the dark or under this low irradiance daylight phototherapy survived $800-900 \mathrm{mg} / \mathrm{kg}$.

Acute toxicity of Beflavin ampules was about 10 times higher. It was clearly demonstrated that this was caused by the stabilizer added.

\section{CONCLUSIONS}

In all probability, comparably large doses of riboflavin will likewise be needed in newborn babies to achieve considerable speeding up of bilirubin photodegradation. In long-term studies in the rats, riboflavin plus phototherapy with low effective irradiance did not reach the effect of an intense blue phototherapy without adjunct. When high flavin doses and a high effective irradiance are applied, side effects on the skin must also be expected in human beings. Moreover, the increased mortality of
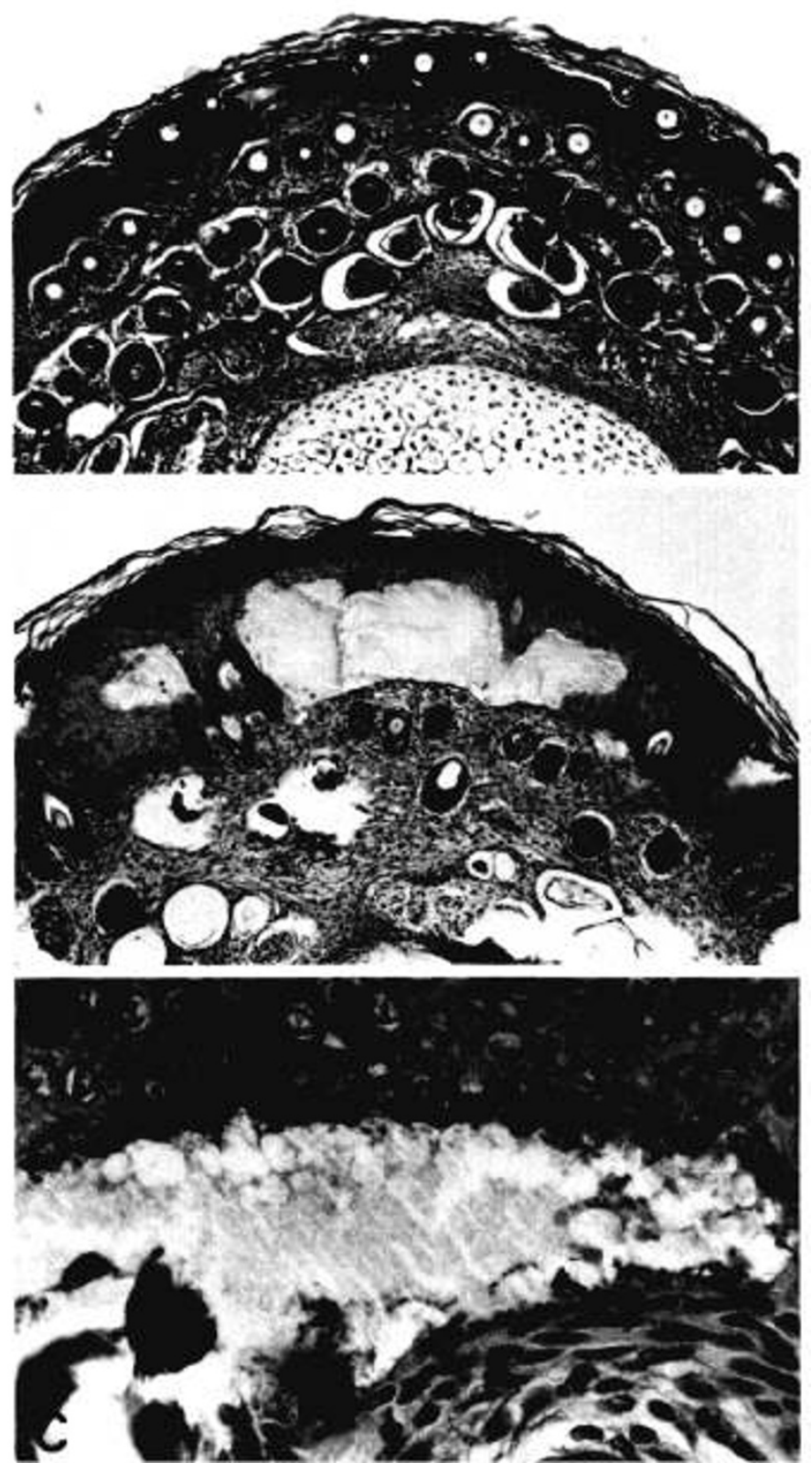

Fig. 7. $A$ Hematoxylin eosin stain of the normal tail of a control animal (magnification 1:65). $B-C$ Histologic features of the blister formation on a tail of an infant Gunn rat. Epidermal colliquation, stratum corneum, and stratum granulosum intact as well as corium and cartilage (magnification $7 b 1: 65 ; 7 c 1: 400$ - sector of the edge of the blister).

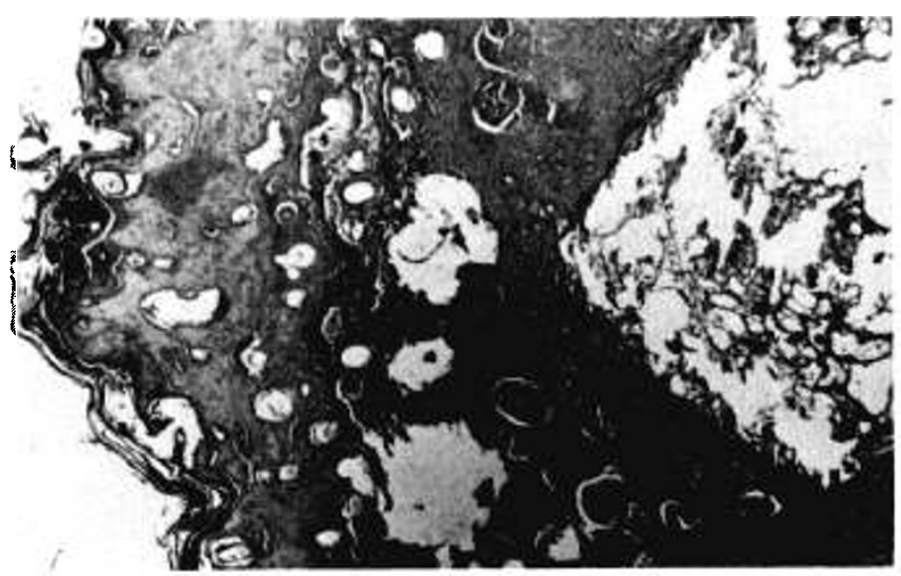

Fig. 8. Complete fibrinoid tail-necrosis, cartilage included (magnification 1:65).

rats under intensive phototherapy as compared to those kept in the dark, points to more general disturbances arising from phototoxic or photodynamic reactions. This may correspond with the above cited observations of Speck et al. (21) and Santella et al. (16), who demonstrated that photoactivated riboflavin will change the structure of DNA.

Several authors (Sisson et al. $(19,20)$ and Gromisch et al. (7), reported on riboflavin deficiency in neonates being provoked by phototherapy. Their results are in accordance with our animal experiments. However, the amount of riboflavin involved is small and likely to be of no major concern. If riboflavin-substitution is considered, it should be administered after phototherapy has been completed and under the exclusion of ampules containing stabilizers.

\section{REFERENCES AND NOTES}

I. Ballowitz, L., Geutler, G., Krochmann, J., Pannitschka, R., Roemer, G., and Roemer, I.: Phototherapy in Gunn rats. Biol. Neonate, 31: 229 (1977).

2. Barka, T., and Anderson, P. J.: Histochemistry. Ist Ed. (Hoeber Medical Division, New York, 1965).

3. Behrens, B., and Kärber, G.: Wie sind Reihenversuche für biologische Auswertungen am zweckmäßigsten anzuordnen. Arch. Exptl. Pathol. Pharmak., 117: 379 (1935).

4. Bunjamin, A.: Induziert Riboflavin während der Phototherapie bei der ikterischen Gunn Ratte phototoxische Reaktionen? Inaug. Diss. FU Berlin (1978).

5. Christensen, St.: Studies on riboflavin metabolism in the rat III Disappearance rate and urinary excretion rate of flavin after intravenous infusion of riboflavin 5'-phosphate. Acta Pharmacol. (Kbh), 27: 41 (1969).

6. Goebel, A.: Bilirubin-Clearance während der Fototherapie bei Gunn Ratten. Inaug. Diss. FU Berlin (1979).

7. Gromisch, D. S., Lopez, R., Cole, H. S., and Cooperman, J. M.: Light (phototherapy)-induced riboflavin deficiency in the neonate. J. Pediatr., 90: 118 (1977).

8. Hanefeld, F., and Natzschka, J.: Histochemical studies in infant Gunn rats with kernicterus. Neuropaediatrie, 4: 428 (1971).

9. Hodr, R.: Urychlení léčebného účinku světla riboflavinem pr̆i fototerapii novorozeneckých hyperbilirubinémii. Cs. Pediatr. 32: 224 (1977).

10. Ippen, H.: (personal communication).

11. Kostenbauder, H. B., and Sanvordeker, D. R.: Riboflavin enhancement of bilirubin photocatabolism in vivo. Experientia, 29: 282 (1973).

12. Lietz, L.: Beschleunigung der Fotodestruktion des Bilirubins durch Riboflavin. Untersuchungen an Gunn Ratten nach verschiedenartiger Flavinzufuhr und differenter Bestrahlungsstärke. Inaug. Diss. FU Berlin (in preparation).

13. McDonagh, A. F.: The photo chemistry and photo metabolism of bilirubin in: Odell, G. B., Schaffer, R., and Simopoulos, A. P.: Phototherapy in the Newborn; an Overview; (National Academy of Sciences, Washington, D. C., 1974).

14. Pascale, J. A., Mims, L. C., Greenberg, M. H., Gooden, D. S., and Chronister, E.: Riboflavin and bilirubin response during phototherapy. Pediatr. Res., 10: 854 (1976).

15. Runge, W. J.: Photosensitivity in porphyria, In: A. C. Giese: Photophysiology. p 149-160. (Academic Press, New York, 1972).

16. Santella, R. M., Rosenkranz, H. S., Brem, S., Lubit, B. W., Erlanger, B. F., and Speck, W. T.: Peroxidase technique for the detection of photochemical lesions in intracellular desoxyribonucleic acid. Pediatr. Res., II: 939 (1977).

17. Sanvordeker. D. R., and Kostenbauder, H. B.: Mechanism of riboflavin enhancement of bilirubin photodecomposition in vitro. J. Pharmacol. Sci., 63: 404 (1974). 
18. Schellong, G., and Wende, V.: Mikromethode zur Bestimmung des Serumbilirubins aus Kapillarblut bei Neugeborenen. Arch. Kinderheilk., 162: 126 (1960)

19. Sisson. T. R. C.: Phototherapy of neonatal jaundice: Effects on blood biorhythms. Abstracts p 43 (VII Internat. Congress on Photobiology, Rome, 1976).

20. Sisson, T. R. C., Slaven, B., and Hamilton, P. B.: Effect of broad and narrow spectrum fluorescent light on blood constituents. Birth Defects: Orig. Art. Ser. 12: $122(1976)$

21. Speck, W. T. Chen, C. C., and Rosenkranz, H. S.: In vitro studies of effects of light and riboflavin on DNA and Hela cells. Pediatr. Res., 9: 150 (1975).

22. Speck, W. T., and Rosenkranz, H. S.: The bilirubin induced photodegradation of desoxyribonucleic acid. Pediatr. Res., 9: 703 (1975).

Copyright $\odot 1979$ International Pediatric Research Foundation, Inc. $0031-3998 / 79 / 1312-1307 \$ 02.00 / 0$
23. Wirjadi, D.: Der Einfluss von Riboflavin auf den Effekt der Fototherapie bei jungen Gunn Ratten. Inaug. Diss. FU Berlin (1978).

24. Wulf, K.: Photodynamisch ausgelöste Lichtdermatosen. In: H. A. Gottron und W. Schönfeld: Dermatologie und Venerologie, p 110-112, Vol. III. I. (Georg Thieme, Stuttgart, 1959).

25. The authors thank Miss Ch. Famula. Mrs. E. Goita, Mrs. R. Ludwig, and Mrs.

H. v. Rheden for technical assistance, as well as Mr. A. Dinzel for the animal care. They are also grateful to Hoffman-La Roche for supplying riboflavin

5'p. and Beflavin, and to Dipl. Phys. J. Pachaly for statistical analyses.

26. Received for publication July 17, 1978.

27. Accepted for publication November 7, 1978. 